\title{
French at the Post-Secondary Level: the CPF Perspective
}

\author{
KATHRYN MANZER*
}

\begin{abstract}
Canadian Parents for French is a national organization dedicated to promoting and creating opportunities for young Canadians to learn French as a second language. This article describes the organization's developing concern at the paucity of opportunities for anglophone students who are fluent in French to pursue bilingual education at the post-secondary level, the organization's role in focusing attention on this issue, and organizational policy as it evolved through regional and national conferences, surveys and reports.
\end{abstract}

\section{RÉSUMÉ}

"Canadian Parents for French" est un organisme national qui a pour but d'encourager les jeunes du Canada à apprendre le français en deuxième langue et de leur en donner les possibilités. L'article qui suit montre l' inquiétude croissante de cet organisme devant le fait que les étudiants anglophones qui parlent couramment le français ont très peu de chances de pouvoir poursuivre leurs études dans les deux langues au niveau post-secondaire. Il souligne aussi quel rôle cet organisme entend jouer en portant son attention sur cette question, et de quelle manière ses principes d'organisation ont évolué à la suite de sondages et de rapports, mais aussi des conférences régionales et nationales.

\section{AN INTRODUCTION TO CANADIAN PARENTS FOR FRENCH}

In March 1977, Canada's first Commissioner of Official Languages, Keith Spicer, convened a meeting in Ottawa of thirty-five parents of school age children to discuss the status of French as a Second Language (FSL) in Canadian schools. In the wake of the St. Lambert immersion experiment (1965), the publication of the first two volumes of the Report of the Royal Commission on Bilingualism and Biculturalism (1967-1968), and the Official Languages Act (1969), parental 
expectations of school systems had been high. However, despite the acknowledged success of the first French immersion programs and the firm commitment of the federal government to English-French official language bilingualism, very little had changed in FSL programming and methodology in Canadian schools other than those in Quebec and the National Capital Region. Parents felt that their children were studying French as they had done, unproductively, a generation earlier, while federal government money was directed primarily to supporting French language training for civil servants. It was the belief of the parents who met in Ottawa in 1977 that the best way to create a truly bilingual Canada was to educate young Canadians in their second official language and that the best investment in bilingualism that governments could make was in supporting second language programs for children. With this conviction in common, the thirty-five parents left Ottawa two days later as the charter members of Canadian Parents for French (CPF).

It was very soon evident that the frustrations and objectives of the fledgling CPF organization were shared by parents across Canada. Five years after CPF's first national conference in October 1977, membership had grown to over 6,000. Today CPF has 18,000 members and, in addition to strong organizations in every province and territory, has almost two hundred active chapters in communities across Canada. Although the size and structure of the organization have changed significantly in its twelve years of existence, CPF's primary focus has remained constant: the first objective of the organization is "to provide educational opportunities for young Canadians to learn and use the French language."

CPF works at local, provincial/territorial and national levels to achieve its objectives through information gathering and dissemination, and through program advocacy. Information relating to FSL for children and young people is gathered through meetings, workshops and conferences, through monitoring school boards and ministries of education, through surveys and opinion polls, through monitoring and commissioning research, through government and organizational publications and public media, and, of course, through direct contact with key groups and individuals. Information is disseminated to CPF members, government agencies, educators and the public through meetings, workshops and conferences, through multi-media awareness campaigns, through CPF's newsletters, books, special reports, registries, kits, and pamphlets and, again, through direct personal contact.

CPF's success as an advocate of excellence in French programming and instruction in Canadian schools is, to a considerable extent, the result of this commitment to thoroughly informing itself and others. At the local level, this advocacy involves working with school boards to ensure that French programs offered are appropriate in terms of available spaces, quality of program, and achievement goals to meet the demand in the community. At the provincial level, $\mathrm{CPF}$ is in close touch with ministries of education. It is at this level of government that policy, curricula, funding and teacher certification requirements are determined and that stable, sequential, well-taught FSL programs have their roots. 
CPF's national organization maintains liaison with the Office of the Commissioner of Official Languages and the Department of the Secretary of State and with national organizations of educators, school trustees and others involved in setting FSL policy and implementing programs.

CPF has always been identified with early French immersion and rightly so. The organization came into existence as the first ripples of the immersion wave were forming and the program and the organization have benefited from each other's successes throughout this twelve year period. Research has consistently found early immersion to be the program through which children learn French most successfully and this success, in addition to increasing demand for the program, has focused interest on other more traditional ways of teaching and learning French. This, in turn, has encouraged increased research on core French and an overall improvement in the quality of that program in terms of the number of hours of instruction offered and level of achievement that a student can expect to attain.

\section{TOWARD A CPF POLICY ON POST-SECONDARY FRENCH}

When CPF became actively interested in French at the post-secondary level, the impetus for that interest was clearly the "immersion wave", the lead classes in early immersion who were approaching high school graduation. But graduating early immersion students were not the only consideration. Aside from the nearly two million children and young people in improved core French programs, there were increasing numbers of students in middle and late French immersion and extended French programs. Collectively, this created a potentially huge clientele for post-secondary institutions to consider and, additionally, a clientele that lacked homogeneity. Students would graduate not only with diverse levels of competence in French, but also with divergent levels of academic ability and commitment to French. As well, students would come from varied economic backgrounds - for some, attending college or university outside their home region would not be an option - and would have a wide range of career goals and cultural objectives. It was apparent to CPF from the outset that there was no single tidy solution to the problem of what opportunities universities and colleges should provide for entering students with significant second-language competence in French.

In CPF's April 1981 newsletter, Dr. André de Leyssac angrily denounced a university system that "has turned its back on the French language ... and on the right of Canadian students to study in French at the university level". Indeed, a CPF Ontario survey of Ontario universities found few courses taught in French (other than French department courses) outside of those offered at the province's three bilingual institutions. However, the survey also discovered potential for course expansion and a willingness on the part of university faculties to communicate and co-operate with CPF in creating new opportunities. From the spring of 1981 onward, the status of post-secondary education in French was a recurring subject in CPF newsletters and an active concern of the organization. 


\section{BILINGUAL UNIVERSITY EDUCATION FOR ANGLO-ONTARIANS}

The CPF approach to French at the post-secondary level was very similar to the organization's approach to French at the elementary and secondary levels: gathering and disseminating information, advocating necessary changes and innovations, and supporting individuals and institutions that were implementing or facilitating promising initiatives.

All of these elements came together at a conference on Bilingual University Education for Anglo-Ontarians jointly sponsored by CPF Ontario and Glendon College, York University, and held at Glendon College in September 1983.

The conference had two clear goals: to evaluate the current status of bilingual university education in Ontario, and to determine what changes were necessary in order to meet the varied demands of prospective students.

The central debate focused on the respective roles of bilingual and anglophone universities in providing French language programs and courses. Ontario's Minister of Intergovernmental Affairs, Thomas Wells, warned that, "In the present economic context, the needs of bilingual education may not all be satisfied as soon as might be desirable" and clearly favoured building upon "the base we now have - at Ottawa, Laurentian and Glendon" to developing courses in French at the English-speaking universities. Laurentian University's President Henry Best echoed this view: "I am not attempting to exclude the non-bilingual universities but I would like to ensure that the bilingual universities can do the job before we begin spreading the resources too thinly across the province." Federal Secretary of State Serge Joyal recognized that cost was a consideration but believed that "costs surely need not be prohibitive if careful choices are made" and that if universities were considered as reflecting Canada, "no reflection of Canada can ignore the impact of the two official languages on the lives of Canadians." The Commissioner of Official Languages, Max Yalden, was characteristically emphatic: "Quite simply, our English-speaking universities are going to have to adapt, both individually and collectively, to changes in students' needs and expectations." Professor François Paré of the University of Guelph claimed firmly that, "Students will go where programs are strong and/or where costs are least. The anglophone universities must adapt. Mr. Wells advises students to go to one of the bilingual universities, but they won't."

At the closing plenary session, conference delegates passed thirteen recommendations, four of which constituted the foundation upon which CPF policy on French at the post-secondary level was constructed and action plans for many universities and organizations were based. Delegates recommended that:

- the Council of Ontario Universities at the level of university presidents seriously consider offering at all Ontario universities, courses or programs in French in disciplines other than French

- university presidents request their deans to identify in the various faculties those professors willing and able to teach their discipline in French; to identify 
what courses could be offered; and to make budgetary adjustments so that these courses can be offered

- all three Ontario bilingual universities be enabled to offer a wider range of courses and that all major disciplines be available in at least one of them so that students who so desire may pursue any program they wish with at least 50 per cent of their courses taught in their other official language.

- cultural experience in language be made an essential component of university curricula and that rapprochement between English-speaking and French-speaking Canadians be made a particular objective of the Ontario post-secondary system.

The conference on Bilingual University Education for Anglo-Ontarians created awareness and generated action in Ontario and other provinces as well as supporting those who were already actively involved in promoting adaptation and change.

1. With varying degrees of intensity, Ontario universities became involved in creating opportunities for bilingual students to learn and live in French. In English-speaking universities, studies were undertaken to identify bilingual faculty members who were able and willing to teach in French. French language services were expanded. Positions of responsibility for bilingualism were created. Pilot projects, usually in the form of subject courses and sections offered in French, were introduced. With the support of the conference, Ontario's bilingual institutions accelerated their expansion of course and program offerings in French.

2. Secondary school educators attending the conference were able to take back to FSL colleagues and students some hope for a diverse continuum at the post-secondary level and additional reasons for students to continue their studies in French at the secondary level.

3. Federal and provincial governments, through their representatives at the conference, were alerted to the need for planning, research and funding for post-secondary French.

4. Research institutes were urged to continue to undertake studies relating to post-secondary French, and their expressed need for adequate funding for those projects was recognized and supported.

5. The general public was made aware of the need for expanded opportunities in French at the post-secondary level through widespread coverage of the conference by Ontario media and through the journals and newsletters of national education-related organizations.

6. Finally, the report of the conference provided a permanent record of the proceedings as well as listing relevant reports, articles, research projects and, through a delegates list, contact people from all areas of involvement. From the CPF perspective, the conference deliberations served as a very effective means of self-education, and the recommendations gave the organization a firm basis for further initiatives and further study. The conference and its recommendations also established a model for CPF regional conferences on post-secondary French across Canada. 


\section{REGIONAL CONFERENCES}

Between May 1984 and October 1985 CPF-sponsored conferences on postsecondary French were held in Vancouver, Ottawa, St. Boniface (jointly sponsored by CPF Manitoba and CPF Saskatchewan), Toronto, and Charlottetown (sponsored by CPF branches in all four Atlantic provinces). In addition, CPF Alberta participated in the May 1984 symposium on The Role of Western Universities and Colleges in Bilingual Education, sponsored by the University of Calgary.

The positions taken in the four basic recommendations of the Toronto conference were reiterated or implicitly supported by conferences in other regions. At the same time, the conferences introduced concerns, issues and recommendations that were regionally specific or that effectively expanded the base position outlined by the Toronto recommendations.

The Calgary symposium (May 3, 1984), at which all but one Western Canadian university were represented, stressed the need for an immediate evaluation of demand for post-secondary bilingual opportunities and preparation of a response to that demand. The symposium also identified the necessity of establishing a centralized source of information regarding French offerings at Canadian universities.

The Vancouver conference (May 18-19, 1984), which dealt with postsecondary education in Western Canada with particular emphasis on British Columbia, recommended that Western post-secondary institutions establish a committee to co-ordinate the expansion of French programs at the post-secondary level, and encouraged co-operation between community colleges and universities with regard to bilingual education.

The conference on French for the Post-Secondary English-Speaking Student held at Carleton University (September 28-29, 1984) illustrated language needs in the workplace, particularly relevant in the National Capital Region, through panelists representing federal and municipal governments, the private sector, and immersion graduates. The conference recommended that departments of French offer language courses suited to a variety of interests and abilities; that post-secondary institutions appoint French co-ordinators; that students be encouraged to select special French options through double credits, pass/fail marks, examinations in French or English, and study abroad in French; and that funding possibilities for the development and implementation of new French programs for anglophone and bilingual universities be studied. As an outgrowth of this conference, the Ottawa-Carleton Chapter of CPF commissioned a survey of area senior immersion graduates in order to assess the students' level of French competence and to determine their future plans relating to French.

The Post-Secondary Bilingual Education Conference: Manitoba/Saskatchewan (April 25-27, 1985) brought forth joint recommendations and recommendations specific to each province. The two provinces stressed: the importance of avoiding duplication of institutional French language offerings by co-operative planning; 
support of a strong, vibrant francophone post-secondary institution; and the urgent need for liaison between secondary and post-secondary institutions.

The Charlottetown conference, Post-Secondary Bilingual Education in Atlantic Canada (October 25-27, 1985), brought forth resolutions by which postsecondary institutions were asked, first, to provide courses in French as necessary to enable core French students to become functionally bilingual and, second, to work with high school guidance counsellors to inform immersion and core French students of available courses taught in French. The conference also urged that the transfer of credits towards degree programs at Canadian universities be expanded and common guidelines developed.

In addition to the recommendations reported above, two issues arose as urgent concerns at every regional conference: the quality of secondary school French immersion, and the training and availability of French teachers. Both subjects are related to French at the post-secondary level, but both are too complex to incorporate fully into a perspective of post-secondary French. However, the emphasis that delegates to all conferences placed on these issues dictates that some specific concerns be recorded.

With regard to secondary school French immersion, it should be noted that all regional conferences had high school student participants and that their observations are included in delegates' comments. Collectively, the conferences recommended that:

- ministries and school boards define secondary immersion in terms of the number of French language courses required

- students be offered more opportunities to speak and write French

- a balanced development of proficiency in all language skills be encouraged

- course offerings be increased, particularly for students in senior grades

- at least 40 per cent of courses taken at the secondary level be in French

- course offerings be appropriate to students' career aspirations in order that students do not have to choose between career preparation and further language acquisition

- post-secondary application forms be modified to show secondary school courses in French

- research and studies in French at the secondary school level continue to be funded.

Concerning teacher training and availability, conference delegates recommended that:

- English competency tests as entrance requirements for French immersion teachers be modified

- linguistic competency examinations for faculties of education be standardized within provinces and that more emphasis be placed on linguistic ability in evaluating FSL teacher training candidates

- provincial joint committees be established to study FSL teacher training requirements

- student teachers spend more time in FSL classrooms 
- immersion teacher candidates receive training specific to that profession

- funding for the training of elementary and secondary FSL teacher specialists be increased

- the possibility of developing French immersion teacher preparation courses on a regional basis with adaptability for provincial concerns be pursued

- professional development and retraining opportunities be provided

- school boards be encouraged to fill teacher vacancies with bilingual staff

- boards seek out teachers within their systems who can teach in French

- secondary school French students be made aware of teaching French as an attractive career possibility

- teacher training institutions upgrade and increase their programs in order to respond effectively to the ever increasing demand for well qualified FSL and FFL teachers

- vigilant care be taken that teacher standards are not permitted to decline.

The responsibility of universities to produce an adequate supply of well trained French teachers and the responsibility of schools to prepare students to study in French at the post-secondary level were clearly seen by conference delegates as relating to French at the post-secondary level.

\section{NATIONAL COLLOQUIUM}

The colloquium, French at the Post-Secondary Level: A National Perspective (Ottawa: March 1-2,1986), represented the culmination of the first stage of CPF's involvement in bilingualism at the post-secondary level. The colloquium brought together fifteen CPF members with special interests in French at the postsecondary level and representatives of the Department of the Secretary of State, the Office of the Commissioner of Official Languages, the Fédération des Francophones hors Québec, the Canadian Association of University Teachers and the Ontario Institute for Studies in Education.

The first issue that representatives addressed was the relationship of francophone and anglophone demands for post-secondary education in French. Francophone and bilingual institutions had been supported in many recommendations from regional conferences, but concerns existed that the escalating demand by anglophone students for courses and programs taught in French at the university level could have a negative effect on francophone university students and their institutions. The colloquium recommended a policy, later approved by the CPF National Board of Directors, by which the needs of the francophone community for quality post-secondary education in its institutions should be recognized and given priority.

With implicit acceptance of the policy base defined by recommendations from the regional conferences, other initiatives arising from the final session of the colloquium were action-oriented.

The meeting endorsed the formation of a CPF working group to study teacher 
training and teacher supply. With that group's recommendations, in combination with those of the regional conferences and the CPF National Board, teacher training and supply as an issue has been given the highest priority by CPF at all levels. In this area, CPF's role has been and will continue to be that of a catalyst, initiating action by others through approaches to federal and provincial ministers, school boards, faculties of education, education-related organizations, media, parent groups, and members of provincial and federal parliaments.

The necessity of liaison between secondary and post-secondary levels was recognized in a proposal that CPF write to the Association of Universities and Colleges of Canada stressing this need.

The importance of continuing and expanded research and study at the secondary and post-secondary levels was identified and, specifically, the request by the Modern Language Centre at the Ontario Institute for Studies in Education for Secretary of State funding for a six year tracking study of secondary immersion students was endorsed.

Recognizing that quality French courses and programs are a component of a quality post-secondary institute, the colloquium recommended the formation of a working group to develop a resolution for presentation to the 1986 CPF Annual General Meeting on post-secondary funding in general and, particularly, funding for French language initiatives.

French at the secondary level as it relates to French at the post-secondary level continued to be a dominant issue. Representatives noted that the quality of teaching was inconsistent, that the drop out rate was high, that students needed more courses, more information and more encouragement to remain in French programs. Again, the subject was directed to a working group with the objective of bringing forward a resolution on this issue for the 1986 Annual General Meeting.

A second recommendation relating to secondary students asked that the CPF Publications Committee consider producing a publication for secondary students explaining why they should continue to study French. The result of this suggestion from the colloquium was the publication in 1987 of a CPF kit, French: It Makes a Difference, which responded not only to the request for motivational material, but also to student needs that had been identified at regional conferences. The heart of the kit is a brochure featuring photographs of notable Canadians - the Prime Minister, athletes, journalists - and accompanying quotations promoting the learning of French. The kit also contains six regional/provincial brochures (BC-Yukon, Alberta, Saskatchewan, Manitoba, Ontario, Québec, and Atlantic Canada) which detail French language courses, programs, exchanges and service available at universities, colleges and, in the case of Quebec, CEGEPs. As well, there is information on SEVEC exchanges, on Secretary of State programs for young people and, from the Ontario Modern Language Teachers Association, a promotional brochure on the teaching of French as a career. The kit, a poster, and an order form were sent to every high school in Canada and the response from schools was very positive. 


\section{CONCLUSION}

Since the first post-secondary conference in September 1983, a number of things have clarified and modified CPF's perspective on post-secondary French. The immersion wave has not come ashore as soon or as forcefully as had been predicted. Problems have been recognized in secondary school level immersion in terms of program design and quality. An urgent need for teachers has been identified. A wider base of relevant research has been created and regional/ national communication and co-operation between universities has improved. There is new information on the status of French at post-secondary institutions, most notably Arthur LeBlanc's study, Bilingual Education: A Challenge for Canadian Universities in the '90s. LeBlanc records how universities across Canada are preparing to cope with the anticipated immersion bulge in the 1990s and, on the basis of interviews and a survey, makes recommendations on what action should be taken. Some funding has been made available, and interesting pilot projects have been undertaken: "sheltered" courses at the University of Ottawa in which subject-matter teaching in French is supplemented by instruction by a second language teacher; support from the university for faculty Frenchfluency upgrading at the University of New Brunswick; "Mention Français", a new program at Carleton University in which anglophone students take subject courses taught in French appropriate to their level of fluency. Many universities have offered new courses, new programs and new services in French.

CPF policy on bilingual university education has evolved gently throughout six years of conferences, recommendations, research surveys, reports and observations, but this evolution has led to an expansion of concerns and objectives rather than a departure from the CPF position of 1983. The organization recognizes the many positive changes that have taken place in bilingual university education but recognizes, too, that much remains to be done. University faculties of education must produce more well-qualified French teachers. Research, particularly research centred on the secondary/post-secondary interface, must be continued and expanded. Structured liaison should be established between the postsecondary and secondary systems and secondary immersion students who want to study in French after graduation must have a wider choice of courses, better programs, more information from the universities, and more encouragement to continue their pursuit of bilingualism. A network should be established to facilitate information exchanges between universities and among universities, research institutes, government departments, and organizations actively involved in post-secondary French. Departments of French should set course levels, content and methodology to correspond to students' fluency levels and objectives. Secondary and post-secondary systems must recognize that it is more difficult for students to achieve academic success when they are studying in their second language and act to ensure that students receive the good counsel, encouragement and generous treatment necessary to instil confidence. Sections and courses in 
which French is the language of instruction should be offered at most Canadian universities, with the number and range of offerings appropriate to the size and location of the university and the intensity of student demand. Successful pilot projects should be publicized and implemented at other institutions. Where cost is a factor, special funding for these initiatives should be provided by federal and provincial governments.

Soon - probably as soon as next year - there will be a quarter of a million French immersion students in Canadian schools. These children and young people are working hard to lift themselves to the edge of bilingualism and the satisfaction and rewards that that can bring. The responsibility of achieving and maintaining bilingualism is, ultimately, the responsibility of the students, but it is a shared responsibility: universities - administration as well as faculty - and governments must ensure that courses, programs and services are in place to enable students to continue their bilingual education and to prevent an exhilaratingly successful language learning phenomenon from stopping short of its logical goal.

\section{REFERENCES}

Biebrich, J., and Van Loon, L., eds. (1986). Post-Secondary Bilingual Education Conference Manitoba/Saskatchewan. Report of the Conference on Post-Secondary Bilingual Education, College Universitaire de Saint-Boniface, April 25-27, 1985. Winnipeg/Saskatoon: Canadian Parents for French Manitoba/Canadian Parents for French Saskatchewan.

Collins, J., ed. (1986). Post-Secondary Bilingual Education in Atlantic Canada. Report of the Conference on Bilingual Post-Secondary Education, University of Prince Edward Island, Charlottetown, PEI, October 25-27, 1986. Charlottetown: Canadian Parents for French.

CPF (1984a). Post-Secondary French in Ontario. CPF National Newsletter, No. 25 (March), 7.

CPF (1984b). Action Recommended for Universities. CPF National Newsletter No. 26 (June), 5.

CPF (1981). What's Wrong at Our Colleges and Universities; Ideas of André de Leyssac; Universities Surveyed. CPF National Newsletter No. 13 (April), 1, 3.

Duhamel, R. (1985). French-Language Programs in Manitoba and Saskatchewan: Post-Secondary Education Challenges. The Canadian Modern Language Review 41(5), 819-26.

Edwards, V. (1987). Working Within System Secret of UNB FSL Teacher Training Program. CPF National Newsletter No. 38 (June), 7.

Edwards, V. (1988). The Teacher Crisis: Retraining Will Buy Some Time. CPF National Newsletter No. 44 (Winter), 7.

LeBlanc, A. (1986). Bilingual Education: A Challenge for Canadian Universities in the '90s. Winnipeg: University of Manitoba Continuing Education Division.

Loughrey, M. (1985). French for the Post-Secondary English-Speaking Student. CPF National Newsletter No. 29 (March), 5.

MacDonald, P. (1984). Parents in BC Meet on Universities. CPF National Newsletter No. 27 (September), 1, 4.

Manzer, K. (1986). CPF Identifies Major Issues at Post-Secondary Colloquium. CPF National Newsletter No. 34 (June), 6.

Manzer, K., ed. (1986). A Report on the Canadian Parents for French (Ontario) Conference on French as a Second Language at Ontario Universities. Toronto: Canadian Parents for French Ontario.

Manzer, K., ed. (1986). A Report on the Canadian Parents for French Conference on French at the Post-Secondary Level: A National Perspective. Ottawa: Canadian Parents for French. 
Manzer. K.. ed. (1988). A Report on the Canadian Parents for French (Ontario) Colloquium on French as a Second Language at Ontario Post-Secondary Institutions. Toronto: Canadian Parents for French Ontario.

Manzer, K., Benson, J., and Greaves, W. eds. (1984). Bilingual University Education for Anglo-Ontarians. Report of the Conference on Bilingual University Education, Glendon College, York University, September 30-October 1, 1983. Toronto: Canadian Parents for French Ontario.

Obadia, A. (1988). The Teacher Crisis: Positive Action Needed Now. CPF National Newsletter No. 44 (Winter), 7.

Poyen, J. (1981). What to Do about Post-Secondary Education. CPF National Newsletter No. 13 (April). 2.

Poyen, J. (1984). Calgary Meeting Reviews Western Universities. CPF National Newsletter No. 27 (September), 1.

Ruest, P. (1985). A Model for French Language Post-Secondary Education. The Canadian Modern Language Review 41(5), 835-41.

Shapson, S. (1985). Post-Secondary Bilingual Education: Identifying and Adapting to the Shift in Second-Language Demands. The Canadian Modern Language Review 41(5), 827-34.

Tardif, C. (1987). Alberta Immersion Growth Places Pressures on Teacher Training. CPF National Newsletter No. 38 (June), 4.

Tourigny, R. (1987). FSL Teacher Supply: A National Outlook. CPF National Newsletter No. 38 (June), 1-2.

Wesche, M. (1985a). Immersion and the Universities. The Canadian Modern Language Review 41(5), 931-40.

Wesche, M. (1985b). What Can the Universities Offer to the Bilingual Student'? The Canadian Modern Language Review $41(5)$, 956-61.

Yalden, J. (1987). French Studies in the Undergraduate Curriculum. CPF National New'sletter No. 37 (March). 10. 